\section{THE EVOLUTION OF ENTERTAINMENT CULTURE IN THAI SOCIETY: FROM SACREDNESS TO POPULARITY ${ }^{1}$}

\section{Patarawdee Puchadapirom ${ }^{2}$}

\begin{abstract}
Associated with the religious, animistic, and ritual aspects in everyone's lifestyle, entertainment culture has evolved to meet the audience's changing preferences and different social status in each era. Whether for the royal court or the commoners, both forms of entertainment were found complementing each other, resulting in its legacy and creation of a new variety.
\end{abstract}

Economic growth not only conveyed wealth to people but also produced an increase in entertainment performances. In the present Ratanakosin period, entertainment has

\footnotetext{
${ }^{1}$ As part of my Ph.D. dissertation, The Transformation of Entertainment Culture in Bangkok Society from 1948 to 1975 , this article would not have been possible without considerable help and valuable guidance from Associate Professor Dr. Dhida Saraya, my advisor, and Dr. Sunait Chutintaranond, my co-advisor. Dr. Dhida Saraya and I acknowledge the financial support of the Thailand Research Fund through the Royal Golden Jubilee Ph.D. Program [PHD/0124/2547].

${ }^{2}$ Lecturer, Department of Music, Faculty of Fine and Applied Arts, Chulalongkorn University
}

witnessed significant changes from sacredness to publicity, while the theme have been based so much on daily life activities that performing artists could really earn their own livings using their skills and diversify the forms of performances more than in the past.

The critical change in entertainment culture occurred during the reign of King Rama $V$, when the general public began to be able to select and pay for its entertainment. Consumer behavior has dictated the creation of the modern musical and performing arts. The royal court and high dignitaries played an important role in assimilating European culture in Thai performances, resulting in lakorn duk-damban (song and dance drama with soft music) and piphat duk-damban (orchestra with pipes). The standard practice of royal court entertainment was established and handed down.

\section{Introduction}

Wathanatham kwam banthoeng is a compound word combining the terms 'entertainment' and 'culture'. It refers to entertainment customs and civilization for public enjoyment.

Coined in the era of Field Marshal Pibulsongkram, the term wathanatham, known as 'culture', was defined according to the 1942 Culture Act as 'characters that indicate cultivation, refinement, perfect harmony, progress, and morality of the people'. Technically it means 'collective behaviors as well as learnt and shared knowledge within their own group' (Royal Institute Dictionary, 1982: 7).

Today, wathanatham also indicates the development of people's ways of living in society and their expressions regarding livelihood, art, and entertainment preferences. 
Defined in the Royal Institute Dictionary, 1999, wathanatham, or 'culture' consists of 'things that create collective development, i.e., clothing culture, collective lifestyles such as folklore, hill-tribe culture' (2003: 1058). Since culture has to be taught and cultivated, it is associated with a particular society, assembles their thoughts, beliefs, and traditions, and conveys these to said society.

Originally, banthoeng means to entertain for exuberance. In Bradley's Dictionary of the Siamese Language (1971: 365), kwam banthoeng refers to 'the joy of the heart', whereas the Royal Institute Dictionary of 1999 defines the term banthoeng as 'cheerful, merry, (v.) to entertain, e.g., 'raikan banthoeng' (entertainment program)' (2003: 617).

In brief, wathanatham kwam banthoeng, or 'entertainment culture' in English, indicates the merry performances which are parts of people's life with various forms depending on their lifestyles, surroundings, and time span.

In the beginning, as far as the terms advancement or civilization were concerned, people usually associated them with Chinese and Indian civilization. As trade and other relationships with Europe prospered, especially in the Ratanakosin period, some foreign groups were brought in to settle down in Bangkok, evangelize, and teach so much art and science that the advanced knowledge and technology became talking issues among the members of high society: King Rama IV, then the crown prince; Luang Nai Sith, who later became
Chancellor Somdej Chaophraya Borommaha Srisuriyawong (Chuang Bunnag); and Chao Phraya Thipakornwong, author of Kitjanukit, a religion-and-science question-and-answer book published during the reign of King Rama IV.

Siam not only embraced European but also adopted to Anglicisms such as the term sivilai, which refers to a cultivated, refined, and modernized culture similar to the Western world's. According to M.R. Kratai Rajothai, a linguist in the reign of King Rama $\mathrm{V}$, the term sivilai was associated with the modern way of life: '[...] King Rama IV is such an expert in European affairs [...] that the sivilai custom came to Siam [...] In the reign of King Rama V, our customs have already improved similarly to the European's. So what good there is to ask for the swift civilization of the country?' (Siam Pra-Peth, vol. II, quoted in Dhida Saraya, 1996: 152)

Apart from modeling after some European countries, the royal court and high dignitaries preferred to show off the national civilization through traditional performing and musical arts which were highly regarded in the Occident. In 1886, a Siamese ensemble was sent to perform at an exhibition in England. To refer to an advanced stage of social development, the term arayatham was later adopted, and promotion and support were poured into the court's performing and musical arts, an attestation to royal civilization. From King Rama VI's speech, 'the country which means to be completely civilized needs to be merry' (Naikuadhumprae, 1918: 39). Therefore, the performing and musical arts were brought in to highlight the country's progress.

Aimed at studying the evolution of entertainment culture, this article will discern the aspects of musical and performing arts 
that reflect long-developed Siamese cultural aesthetics in different social backgrounds.

Records of the term dontri date back to the Sukhothai period. It refers to musical performances both for pure pleasure and for ritual accompaniment in the animistic belief system. (Prachoom Silacharuk part I, 1977: 66). Associated with several daily life activities in terms of faith and rituals, musical arts have witnessed a long development through the evolution of musical instruments and typical group performances. However, in the early Ratanakosin period, mahori ensembles including stringed instruments and a tuned percussion ensemble, or piphat, ${ }^{3}$ as a whole were called dontri, as in the expression prakom dontri, which meant 'to play music' (Bradley, 1971: 217). Although more definitions have been added over time, dontri has the same meaning of sensational melodies and singing (Royal Institute Dictionary, 1982: 394).

Having been mentioned since the Ayutthaya period, the term mahorasop refers to festivities provided by the royal court in each ceremony. Coming in the form of performing arts, they include khon 'masked play', hun 'puppet show', lakhorn 'dance drama', nang yai 'shadow play', ngiu 'Chinese opera', tai luat 'tightrope acrobatics',

\footnotetext{
${ }^{3}$ Piphat is a musical instrument used to play in rituals and in supporting performances. The early ensemble of piphat was called piphat khrueng har, or five instruments; piphat consists of $p i$ 'oboe', ranad-ek 'xylophone', gong, glong tahd 'drum', and ching 'cymbals'.
}

mong khrum, rabeng, kra-ua thang kwai, yuan ram khom. ${ }^{4}$

In the early Ratanakosin period, various amusements in the royal celebrations to entertain fairgoers were also called mahorasop. According to Bradley (1971: 508), mahorasop was 'the celebration in the royal funeral such as king's funeral', while today its meaning has been reduced to joyous performances, e.g., khon, lakorn' (Royal Institute Dictionary 1982, 2003: 837).

Of any other origins than pure enjoyment, the court and public musical and staged performances were meant to accompany religious rituals. Forced afterwards to recede from solemn events, they were targeted to satisfy a wider public. Based on the historical approach, derived from the concept of changing consumption, the paradigm shift from solemnization to public entertainment led to new entertainment folklore. Gaining a wider popularity among commoners, certain kinds of musical and performing arts required professional performers as well as a larger variety of performances. As a result, a modern development opportunity was permitted to create various kinds of ensemble and epic performances such as khon, nang, hun, lakhorn phun-thang 'historical setting dance drama', li-kay 'popular folk drama', lakhorn duk-damban 'song and dance drama with soft music', and lakhorn rong 'dance drama operetta'. Studying the evolution of entertainment culture from the dawn of Thai history to the reign of King Rama V, this article will cover the many crucial phases, the substantial growth, and the promotion of royal performing arts as a cultural inheritance that underscored the country's civilization.

\footnotetext{
${ }^{4}$ These are royal entertainment performances in celebration fêtes.
} 


\section{Entertainment Consumption: From Sacredness to Popularity}

Associated with Brahman rituals rather than Buddhism and influenced by animistic beliefs, entertainment culture has shadowed every stage of human life. In the past, laboring on the land, peasants worshipped inanimate objects and natural phenomena, causing basic faith in personal rituals and seasonal festivals such as the khwan duen celebration, kon phom fai, kon chuk, funeral rituals, thod kath, thod pha-pa, and the pilgrimage to pay homage to the Buddha's footprint and his relics. The sacredness of musical and performing arts in rituals was long established. Some ancient myths mention that men played musical instruments, sang and danced along for God, or than luang, so that subordinate deities would descend to earth to teach them to play other instruments such as drums and gongs, dance, and sing songs accompanied by lyre and piphat ensemble. Therefore, the making of offerings as well as the payment of homage to art gurus or masters by musicians and dancers became a common venue for debuting each new performance (Prachoom Pongsawadan part II, 1963: 143).

\footnotetext{
${ }^{5}$ These are names of traditional Thai rituals. Khwan duen is a celebration at first month of birth ; kon phom fai is the first cutting of infants' hair ; kon chuk is the cutting of the topknot hairstyle worn by Thai children, to indicate the end of childhood ; thod kath is the offering of robes to monks during Buddhist lent ; and thod pha-pa is the off-season offering of robes to monks.
}

Initially connected with sacred ceremonies, traditional music and performing arts complemented rituals, oblations, and meritmaking. According to inscriptions from the Sukhothai period, lyres, gongs, klong, piphat, and dances were involved in the ceremony of Lord Buddha's footprint establishment at Suwannakut mountain (Prachoom Silacharuk part I, 1977: 66).

Their roles became more exorcism-oriented during the Ayutthaya period. Whenever inauspicious incidents occurred in the royal palace, be it death caused by slaves' fighting or miscarriage, a ritual concert of 'dances, piphat with lyres, gongs, drums, all playing' (Tra Sam Duang Law, vol. III 1962: 183) together with offerings were executed to ward off evil spirits.

Records from the Ayutthaya period stated that in case of chasing ill-omens, monks were invited to chant 'phra parit' while decorated sets of offerings called bai-sri were arranged and a piphat ensemble including a vertical gong circle (kong wong) were played. '[...]If evils are to be warded off houses, orchards, and fields, invite seven monks to chant 'Phra Parit' for three days, make three tiers of offerings, one set of bai-sri, one duck, one chicken, one bottle of liquor [...] piphat, kong wong, master of ceremony [...]' (Tra Sam Duang Law, vol. III, 1962: 183).

From ritual accompaniment, the traditional music and performances moved on to identify social status. Since the monarch was revered as a divine being, royal ceremonies had to be elaborate to enhance the royal supremacy. In this regard, regally exclusive instruments associated with Hindu deities included the mahorathuk drum, trae 'trumpet', shankha 'conch shell', bandoh, another kind of drum. 
Symbolic of the Ayutthaya kings' divinity, trae and shankha ensembles were stated by Abbé de Choisy as follows:

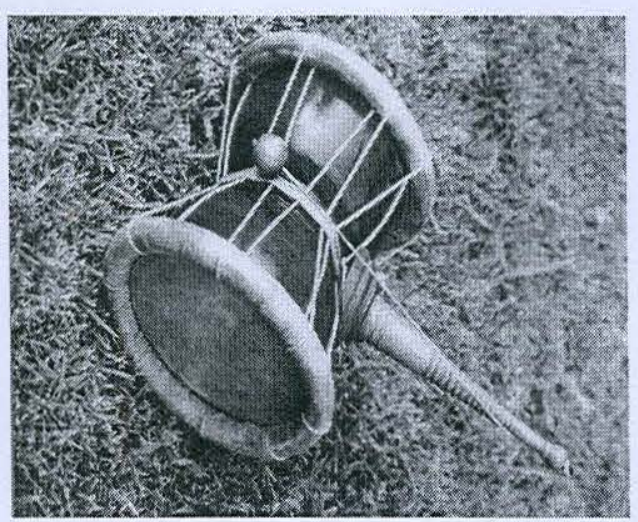

\section{Bandaw}

When peers of high status all sat down in their seats, trae, shankha, and mahorathuk drum were blasted out from inside, signaling the king's entrance to the throne hall [...]. Then, similar sound of trae, shankha, and mahorathuk drum were heard again, signaling the royal departure (La Loubère 1983: 374-382).

By the influence of Hindu deities and their sacred power, the kings' divinity was demonstrated through rituals, literary works, and performing arts. Derived from the Indian Ramayana depicting the extolled Phra Rama, an avatar of the deity Narayana, the Ayutthaya version of the Ramakian epic mirrored the belief in the Siamese kings as the Narayana avatar to rule and help people. Concerning the performing arts, the Indra Phisek royal ceremony (the coronation of Indra) in Kot Monthien Ban 'royal law' and the Chak Nak Duk Damban also arose from Ramayana. In this staged performance, the Hindu gods and demons came to help to churn out amarit nectar but ended up fighting to gain possession of it. Winning, the archangel Indra was crowned Lord of Tawatingsa heaven, resulting in the so-called Indra Phisek coronation. Thus, Narayana and Indra embodied the supreme kingship. Successfully attracting every social class, the Ramakian-based performances came in khon 'masked play' and nang yai 'shadow play'. Khon versions were governed by the classic formalisms of narrative verse rai yao and dialogues, specific choreography, music, and masks.

Recognized as a top-class performance, nang yai originated out of superstitious beliefs. Attention was paid both to the creation of a series of deity puppets out of cow leather and to the performing procedure. Only the hide of a cow bitten to death by a tiger or dying of miscarriage would be destined for the Isavara and Narayana deities, while tiger or bear skins were reserved for the ruesee 'Hermit' puppet by reason of their strength. And as usual, the show started with paying homage to the Lord Buddha, patron deities, and art masters.

Initiated in the royal court as a key program item in various royal ceremonies, the masked and shadow plays featured the divine kings' grace and omnipotence. Their grandeur and exquisiteness were so impeccable that viewers' thirst outside the palace has never been quenched. Later on, although some minor adaptations unavoidably took place from time to time to please the spectators of different eras, ${ }^{6}$ the unique and strict performing etiquettes have remained intact.

\footnotetext{
${ }^{6}$ The development of nang yai could only be accomplished by inserting dialogues or supporting shows such as rabam, lakhorn, and khon. Khon
} 


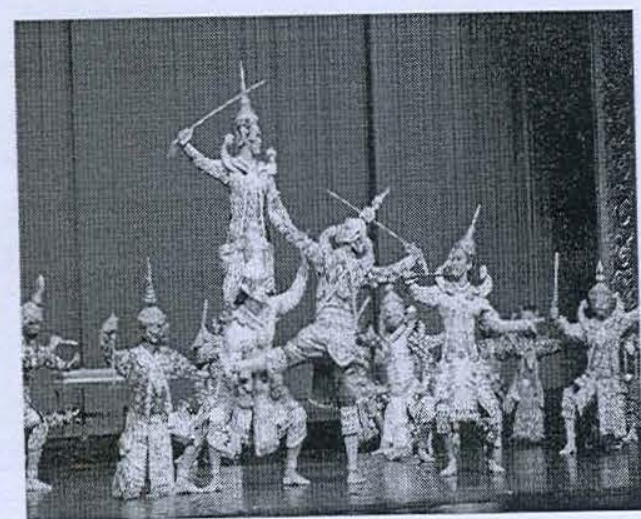

Khon

Eventually, the ceremonial and ritual sacredness has gradually been lost. Seeing its role in ritual accompaniment diminish, the performing arts opted for the exuberance of a wider consumer base. The former god-praising dance (rabam) appeared in such merry celebrations as Chong Priang in the Ayutthaya period (Tra Sam Duang Law vol. I, 2515: 141). Moreover, other forms of pleasureoriented entertainment included mahori 'a stringed instrument ensemble', hun 'puppet show', and len pleng. 'witty male-and-female duo'. However, the diversified pleasure-oriented entertainments reflected different social classes' preferences. The traditional court mahori dating back to the Ayutthaya period was not greatly appreciated outside the palace.

Nevertheless, some folk characteristics were able to infiltrate into the palace as well. Since the Ayutthaya King Boromkot's reign, lakorn nai has been a perfect blend of masked play and

that were performed in support of nang yai were later called khon na chor. lakorn nok. ${ }^{7}$ But lakorn nai's formalisms were based on court arts including graceful dancing gestures, lavish costumes, and beautiful music. And, most importantly, the fascinating theme of lakorn nai concerned royal heroes, including the Indonesian $E-N a O$, the Indian Ramayana, and Oonarut, depicting the deity Krishna, one of the Narayana avatars (Damrong Rajanubhab, 1965: 1).

The performing and musical arts played an active role in daily life inside and outside the royal court. Based on collective beliefs, rituals set to traditional music and performing arts were encountered in every stage of life. The traditional overtures by the piphat ensemble were meant to invite gods to preside over the ceremony. Every movement denoted a specific gesture by a deity. For example, phleng samur described the deity's departure from celestial abodes, phleng klom was characteristic of the arrival of the supreme god, i.e., Narayana, and phleng chamnarn was typical of the supreme god's blessing. In addition, the slow phleng rub phra was arranged to greet the monks' arrival, while phleng song phra with phleng grown nai and phleng cherd tones were played to send them off after the chanting. This implied the return of presiding gods. After the formal religious rituals, many forms of performing arts, i.e., lakhorn and rabam 'dances in a group' were staged to provide a spectacular closing for such ceremonies as cremation or the inauguration ceremonies of preaching and ordination halls and Vihara. La Loubère, the French ambassador to Ayutthaya court, mentioned in his letters that 'the lakhorn troupes were often hired to play in the temple to celebrate the inauguration of a new church or assembly halls where the principal Buddha

${ }^{7}$ Lakhorn nok are play performances by male performers only, focusing on pleasure and fun rather than graceful dancing and beautiful music. 
image was housed' (La Loubère, vol. I, 1967: 548).

In the Ayutthaya period, commoners enjoyed various kinds of the entertainment: dontri, singing, rabam, lakorn nok, hun, len phleng, cham-aut, and mon ram (Mon Dance). La Loubère's record stated that they usually spent their free time in the evening on klong tohn 'single drum' rhythmic singing (La Loubère, vol. I, 1967: 305). In Kham Hai Karn Khun Luang Wat Pradoo Songtham' (1991: 12), villagers' attachment to music was represented by the mentioned musical instrument neighborhoods including thub 'a kind of drum', tohn 'another kind of drum', chang nong 'a small mouthpiece instrument played by jerking with string', plia 'played by flicking', and khlui 'flute'.

Although derived from court entertainment, public performances morphed into a more vulgarized and colorful version to ensure the commoners' satisfaction. The ceremonious rabam left a number of etiquettes behind once it was performed outside the court. According to $\mathrm{La}$ Loubère, the traditional dance outside the court became less formal and ended with slapstick comedy: '[...] the group moved in a circle only [...] just a bit more of arm and body contortions [...]. However, two men came on stage to amuse the audience by cracking a joke for coarse merriment'. (La Loubère, vol. I, 1967: 218). Unlike the royal ceremony of tham khwan 'making soul' accompanied by the exclusive tham $k$ hwan tune, the commoners not only welcomed auspicious melodies but also concluded them with the master of ceremonies reciting a faith healing and joyous rhythmic verse similar to the feast of Thet Maha Chat or the Sermon of the Great Incarnation of the Lord Buddha.

Since most of the festivities encouraged public participation, the key to their success was that the crowd was looking forward to enjoying themselves by participating in the royal celebration rather than just watching the shows. Sponsoring khon 'masked play', nang 'shadow play', hun 'puppet show', lakhorn, ngiu 'Chinese opera', and others in various royal celebrations such as the Emerald Buddha celebration in the Thonburi period, the court acted as main entertainment provider to local people:

[...] three stages of khon, two stages of female dance, one stage of ngiu, one stage of nang klangwan [daytime shadow play], and two stages of Laotian puppets. At night, there were nine screens of Thai nang wang ratha, two screens of Chinese nang. Altogether there were 11 stages. [...] In the east of the venue, was located one stage of Laotian lakhorn, one stage of Khmer lakorn, one stage of Chinese ngiu, and one stage of Vietnamese ngiu. In all, there were four stages [...] In the west, there were one stage of ram wang ratha, two stages of khon, two stages of female dance, one stage of ngiu, one stage of Mon puppet [...] (Krom Luang Narintharadavee, 1978: 155-56). 


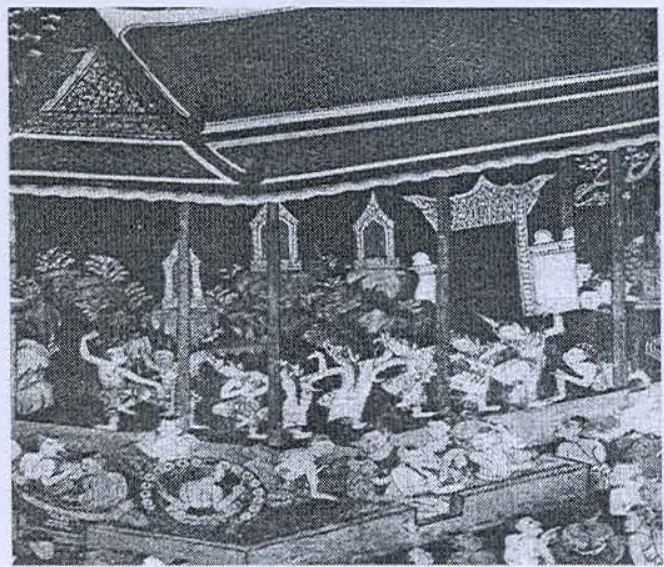

\section{Lakhon}

It can be concluded that in focusing on preserving divine kingship, the court music and performances exemplified the aesthetics of arts and monarchy, while the public promoted exultation and merriment. In addition, the more the public's quality of life improved, the more entertainment they consumed, popularized, and eventually diversified. The court still conserved the unique custom of music and performing arts especially during the Ratanakosin period.

\section{Entertainment Culture in Changing Social Contexts (During the Reigns of Kings Rama I-IV)}

Established in 1782, the new capital of Ratanakosin was modeled after fallen Ayutthaya and Thonburi, governed by the political, social, and religious hierarchy of the sakdina system. ${ }^{8}$ The

\footnotetext{
${ }^{8}$ The sakdina system is a political and social hierarchy determined by the amount of land attached to each person according to his status.
}

sakdina gradings recognized individual landholdings according to their social status and titles: royal, civil service, or military. For example, a phrai held the lowest grading of 5 . Under this munnai -phrai system, standing at the bottom of the status pyramid topped by the monarch, phrai had the obligation to serve and pay tribute to their superiors in the form of labor and produce.

In the early Ratanakosin period, Siamese trade with foreign countries resulted in economic growth back home. Such powerful high dignitaries as the Bunnag were fully involved both in the royal junk trade with China and in their own trade with European countries: England, Portugal, etc. Taking advantage of the economic expansion in Singapore, the British commercial hub in Asia, Bangkok became another lively mercantile port and marketplace. In 1826, during the reign of King Rama III, the Burney Treaty was signed, allowing the British to trade freely with Siam. The expansion of foreign trade also increased consumption among the growing number of well-to-do phrai. Their fortune was confirmed by their method of religious contribution. The wealthier they became, the more merit they made and the more construction and restoration of temples mushroomed. Thipakornwong (1961, vol. II: 172) recorded that: 'some royal family members and high dignitaries had five temples all newly built and twenty-five renovated. Altogether, they were thirty. And more had been built with the support of royal family members and high dignitaries, Chinese men of wealth, well-todo people, and Buddhist abbots, in the garden, the neighborhood, and many towns'.

The evidence from that time points to several nouveaux riches who could afford to construct temples: Wat Nai Rong Temple, Wat Mai Yai Fang Temple, and Wat Duang Kae Temple. Economic prosperity was 
mirrored in the general public's religious contributions, improved quality of life, and new and renovated venues for various religious ceremonies, which were set to the music of piphat ensembles and incorporated theatrical performances, thus enhancing in proportion the traditional entertainment culture.

\section{The Development of Entertainment Culture Publications}

The economic expansion not only generated income but also improved the public's livelihood. To host a spectacle in a ritual ceremony was considered a way to show off one's social status. Although part of ceremonies and rituals associated with animistic beliefs, the entertainment productions were designed to satisfy the general public, their new patron, and were diversified to meet consumers' varied aesthetic requirements. At this point, the courtincubated troupes of artists who dispersed outside for their survival started to nurture the professionalism that was instrumental in the advancement of entertainment culture. The ritual accompaniment music and performing arts targeted more at providing the general public with a good time. Pallegoix (1977: 205) commented that, in the reign of King Rama III, the tonsure ceremony was proportional to the grandness of the person: ' $[\ldots]$ the rich have lakhorn, and prolong the feast for two or three days, according to their means.'

Owing to the soaring entertainment demand in traditional ceremonies, the awakening in the performing arts arena tempted performers to sharpen their skills in ways that could be translated into both fame and finances. Additionally, the performances were diversified and popularized. For example, the typical khon branched out into khon nang rao, khon rong nai, and khon nah chaw. The original piphat ensemble added a new aspect to the nighttime ritual accompaniment by playing a hilarious tune to complement the singing of rhymed poetry.

The function of the piphat saypa ensemble, which played amusing songs such as pleng saypa for pleasure, changed in the reign of King Rama II from simply complementing the singing of rhymed poetry into doubleinstrument ${ }^{9}$ in King Rama III's reign. Simultaneously, a revolutionary development was also noticed among other musical performances such as the double-instrument mahori orchestra. Furthermore, phleng sam chan 'andante' was created to double the length of the notes from the original phleng song chan 'moderato'. To perform the phleng diaw 'solo', musicians had to be able to master the instrument to the extent that tactful movements (look lor look kat) ${ }^{10}$ were created.

The modern development wouldn't have been possible without the musicians' devotion, motivated by incentives, competitive attitudes, and creativity. Mentioned in Saypa Kun Chang Kun Phaen, several famous piphat masters in the reign of King Rama III

\footnotetext{
${ }^{9}$ This denotes a medium-sized precussion ensemble, with another instrument of each kind added, making a pair of each, thus labelled a 'double' ensemble.

${ }^{10}$ This is a method of music playing which divided the instruments or singers into two groups. If the second group plays or sings the same tunes as the first group, it is called look lor. If the second group plays or sings in different tunes from the first, then it is called look kat.
} 
included Khru Kaew, Khru Pak, Khru Thong-in, and Khru Mee Khaek. All of them defined their identities, music schools, and families such as Ban $\mathrm{Ka}$ min style, the Duriya Praneet, the Toh Sa-nga.

Considerable growth occurred in theatrical careers because the wellknown lakhorn chao krub recognized for its graceful dance, funneled in so much revenue for the troupe's artists that they were able to build Nai Rong Temple. ${ }^{11}$ Even some members of the royal family practiced the dance-drama for hire. Among them were Phra Ong Chao Duang Prapha 'Tui' and Phra Ong Chao Suda Sawan 'Puk', daughters of King Pin Klao (Rama IV, 1978: 147).

The rising careers of entertainers were proportional to people's income and to the number of gamblers in the increasingly common gambling houses. Thousend Harris, the English ambassador (1961: 70) talked about their growth in the reign of King Rama IV: It is said that over 300 vicious gambling houses were operated on floating houses, and thousands more were located on land.' Such large numbers of establishments involved in gambling resulted in fierce competition for customers, and one of attractions

\footnotetext{
${ }^{11}$ After King Rama IV had lifted the ban on commoners to own lakhorn nai, a form of royal regalia performed only by the court's female dancers, a new form of entertainment in contrast to the commoners' lakhorn nok performed by male dancers was offered to the public and a rising career of entertainers was opened to female artists.
}

they provided to draw people in was the free spectacle. Prince Damrong Rajanubhab (1965: 172) mentioned that ' $[\ldots]$ owners of the gambling house were prone to hire female dance-drama troupes to perform in their premises so that the audiences would proceed to the thua po game'.

The artists' proliferation in the ceremonies and gambling houses was represented by the first imposition of a khon-lakhorn tax in 1859, which covered popular spectacles at that time: khon, lakorn, phleng, khaen, Mon dance, tawai dance, Siamese puppets, nang yai, ngui, Chinese puppets, Chinese nang (Damrong Rajanubhab 1965: 175). Therefore, it is obvious that in the early Ratanakosin period, professional artists played an active role in the development of popularized entertainment culture, enabling its growth parallel to the ongoing socio-economic expansion.

\section{The Development of Court Entertainment}

Although the flourishing entertainment culture offered a new variety of performing arts to the masses, the classical performances from the Ayutthaya court were resumed as part of the public festivities in various royal ceremonies. In honor of the king, staged theatrical performances were including khon, lakorn nai, hun luang 'royal puppet', and nang yai.

King Rama II, as a great patron of classical arts, played a vital role in the adaptation, creation, and standardization of entertainment culture. As the accompaniment of rituals and theatrical performances, piphat ensembles were adapted to associate with saypa. For lakhorn nai, a revision can be observed in terms of plot and choreography. For the royal lakhorn troupes, King Rama II even 
recomposed the Javanese tale of E-Nao and the Indian Ramakian in order to set a standard of dancing. After that, some famous dancing virtuosos, such as Prince Pi-thuk Montri, Nai Rung, Nai Thong-yu, were responsible for choreographic fine-tuning to set a new standard. By changing the melodies and dancing patterns, the folk art of lakhorn nok was designed to serve as basic dancing positions and typically staged in the palace (Damrong Rajanubhab, 1965: 140-42). Later on, the royal standard of dancing was embraced by commoners, leading to the broadening of the dance-drama horizon ever since.

The evolution of classical music and dance drama were in debt to the royal court that had played an important role in setting standards while the general public entertainment was growing in forms of diversity in proportion to the economics and according to the public's living standards.

\section{The Evolution and}

\section{Consumption of Entertainment Culture during the Period of Modernization in the Reign of King Rama V}

In the reign of King Rama V, economic expansion together with the abolition of slavery and the sakdina system allowed income-earning opportunities and more entertainment consumption among the general public. Relevant entertainment culture was growing in terms of diversity and popularity. Among the new creations were drama lakhorn phun-thang 'historical setting dance drama', li-kay 'popular folk drama', hun kra-bok 'puppet show', lakhorn rong 'dance-drama operetta'. Additionally, the court and high dignitaries churned out a great variety of productions that eventually became popular in society. Lakhorn duk-damban 'song-and-dance drama with soft music' is one example. Simultaneously, whether khon, lakhorn, or music, the court culture was passed on from generation to generation to form the national identity, an indicator of the country's civilization.

As a result of the free-trade treaty and obligations with several European countries prior to the reign of King Rama V, Siam was eventually introduced into the world arena. Realizing the importance of modernization, King Rama V visited Europe twice to strengthen Siamese relationships with European superpowers and to study their civilization, together with those of their colonies in Southeast Asia, i.e., Malaya, Singapore, Batavia, Lanka, India, and Burma.

In 1868 , the state began phasing out slavery and the sakdina system. And, marking the end of the conventional manpower control, the Conscription and Slavery Act was promulgated in 1905, resulting in a high supply of independent labor. Some turned to supplement the agricultural sector by working as rice farmers, others practiced their careers in towns. Being able to freely earn a living along with the increasing economic growth, the general public had such a better financial security that the first Siamese bank was established in this reign.

Acquiring more consumer power, the general public stepped up to patronize the performing artists. Parading the candidate (nak) to the ordination hall in a temple, the colorful procession gave first priority to merriment in the ordination ceremony. As a newcomer from the Occident, trae wong 'the brass band' was a must to lead and entertain the guests. 
Thoed thoeng 'the drum dance' was another thing that was not to be missed. One document indicates that:

Processions come in many forms $[\ldots]$ but the usually seen is led by a European brass band. [...] The other equally important and undeniable instrument in the candidate procession is the long drum dance. Three to four long drums are played by members of the group competing with the beats of cymbals, gongs, and wooden rhythm clappers. While hitting the instruments with their hands or elbows, they perform playful gestures to make the viewers laugh [...] (Latthi Thamniam Tang Tang, 1972: 683-84)

Taking different courses, the ritual and popular entertainments showed themselves in their true colors. The rich spent their money on entertainments to exhibit their financial status. Since the troupes were hired to perform, their sole entertaining value in the royal ceremonies has become profit-oriented instead of emphasizing the status of the host and audience. The motive for the first paid entertainment at Prince Theater in 1883 was for the rich to discriminate against the poor. '[...] it was comfortable for ladies and gentlemen who wished to come and watch the show without having to mingle with smelly-shirted or shirtless pests $[\ldots]$ therefore, they were willing to pay for the tickets collected by Prince Theatre at this time' (Siam Sa Mai Report, vol. II, 1884)

Following the debut of the paid spectacle, the custom of entertainment consumption changed forever. The lucrative business not only did the theater owners good but was also able to bring in so much new creativity in response to the ever changing demands of the audience that conventional entertainment was completely replaced.

Although embracing some new styles at the beginning, entertainment in the reign of King Rama V was still based on classic plays from the late Ayutthaya and early Ratanakosin periods. For examples, lakhorn phan thang featured Sam Kok, Rajathiraj, and Phra Lor, while the popular li-kay or 'folk drama' depicted princely heroes such as Kawi, Thina Wong, and Sankh Silp-chai and the hun krabok 'puppet show' usually presented Phra Aphai Manee. All of these were recognized for their concise plots, lavish costumes, and so on.

Typical of foreign characters, lakhorn phan thang paid more attention to the matching national costumes, which distinguished them from other dramas. In Rajathiraj, the characters were dressed like the Mon but in Sam Kok, Chinese costumes were provided. As for hun kra-bok, the puppets were scaled down to a compact size for easier manipulation and amusing presentation.

Derived from the Indian chanting in the royal funeral ceremony in 1880 , the popular li-kay folk drama started with li-kay ban ton, featuring each ethnic group's language and costume, ranging from the Indian and Burmese to the Chinese and Vietnamese, along with many others. These addresses in different languages attested to another aspect of the entertainment evolution, which was attempting to satisfy audiences of different nationalities and create performance diversification.

After that, li-kay look bod was formed with the accompaniment of a piphat ensemble. 
Derived from li-kay song krueng, the dance drama showing lavish costumes made of heavy brocade and adorned with jewelry, actors of li-kay loog bod wore gaudy costumes and interpreted the tales of lakhorn nok through sequences of graceful moves. With characteristically creative productions, swiftly moving, amusing plots, and realistic acting, li-kay, a satirical form of lakhorn, became very successful with viewers.

\section{High Dignitaries' Entertainment Culture}

Widely opened to European technologies and cultures, Siam was, nevertheless, not completely Westernized but instead enjoyed a perfect harmony of local and foreign customs. Once watching a foreign opera and ballet, King Rama V made a comment on some of their unfitness in Thai culture:

[...] Farangs jumped up and down, using quick step. In Thai people's mind, the gesture could look disgraceful. Wearing short skirts, they danced and indiscreetly lifted them like Samae monkeys. It was a shame for ladies to do so $[\ldots]$ watching a play called Chatterley [...] The ladies wore clinging satin trousers $[\ldots]$ danced indecently [...] It would be considered skirtless for Thai drama. Surely, Prince Thewes would not allow his actors such dressing. Even if he did, the actors themselves would not be willing [...] (King Rama V, 1970: 431-42)
The royal critiques against foreign improprieties in local culture affected the high dignitaries' mentality. As a result, an entertainment adaptation took place by welcoming the realistic acting, concise plot, and quick proceedings of the Western drama for the creation of the popular piphat dukdamban, lakorn duk-damban, lakorn rong.

Influenced by the Western chorus, the piphat duk-damban ensemble featured a choral group singing Thai songs and a deepsounding or alto-key musical arrangement. Thus, it was the classical Thai ensemble with European accent. The lakorn duk-damban also followed in the footsteps of the piphat duk-damban.

Similar to court drama and opera adaptation, lakhorn duk-damban focused on both graceful dancing and beautiful opera songs performed by the actors alone. The proceedings became faster for lack of narrative plot, but, without question, the audience was able to understand the actors' interpretation.

Another opera adaptation was the dancedrama operetta known as lakhorn rong. In this kind of performance, the actors sing with the support of a piphat ensemble, but the realistic acting focused on a realistic setting, authentic costumes, and swift proceedings. Moreover, lakhorn rong dealt with the theme of the changing social context, as seen in Sao Krue Fah, composed by Prince Narathip Praphanphong.

The European influence in local entertainment reflected a cultural revolution in Thai history. One of the virtues was the ability to blend the Western style into the classical Thai. Therefore, the general public was into the novelty. Since culture was symbolic of the national civilization, the entertainment culture was inherited, adapted, and improved by the royal court and high 
dignitaries, so that the classical Thai performing arts, including khon, lakhorn ram, and nang yai, highly recognized for their stately production and the exquisite refinement of their performances, would be passed on from generation to generation to trumpet the richness of the country's cultural history.

The rise of a wide selection of entertainment to meet the general public's demands lessened the role of the courtly performing arts in the general public's life. The strict formalities of the court obstructed the entertainment's evolution in different social contexts. Khon and lakhorn nai had long been reserved for royal consumption. Although hired by the court to perform only in the festivity sessions of the royal ceremonies, nang $y a i$ and other forms of entertainment including rabeng, mong krum, kula ti mai, and thang wisai had to follow court etiquette rigorously. Therefore, it was difficult for them to prosper. Some performance types, such as hun luang 'royal puppet show' became extinct because their giant size rendered them difficult to manipulate.

Formerly the main source of distraction for commoners, the court entertainments were replaced due to the growth of public entertainment, ${ }^{12}$ but their royal and classic values were handed down as a national treasure and eventually nurtured by Krom Mahorasop or the Performing and Musical Arts Department. In charge of

\footnotetext{
${ }^{12}$ For instance, in the royal funeral of King Rama V there was no mahorasop, as had been royal tradition in the past.
}

the training and staging of performing and musical arts, especially khon, the Department saw to it that techniques were handed down from khon masters: Khun Rabampasa and Khun Pamnagnujanekorn teaching at the residence of Chao Praya Thewetwongwiwat (M.R. Larn Koonchorn). As head of the Khon Division in the reign of King Rama V, Thewetwongwiwat inherited the art of khon from Krom Pitakthewet (forefather of the Koonchorns) in the reign of King Rama III (Thanit, 1991: 48-52).

Originating in the court of King Rama II, lakhorn nai derived from the play of Prince Singhanat Rajdurongrit, who had adopted King Rama II's dramatic formalisms. It was later passed on to Chao Phraya Thewetwongwiwat (Damrong Rajanubhab, 1965: 203). When the performing and musical arts were transferred to Krom Mahorasop Luang in the reign of King Rama VI, the formalisms of court drama since the reign of King Rama II were preserved under the auspices of the Krom Sillapakorn or the Fine Arts Department. ${ }^{13}$

Having ripened into another form of divertissement among high-society members, Thai classical music was promoted to the extent that its customs were established. It is understood that the wide spread of novelty entertainments could divert high dignitaries' interest in Thai classical music, especially the piphat ensemble uniquely recognized for its wider range of pitch. Each musician could vary the tune, adapt it to the character of the instrument, and eventually deliver great fun. Soon, piphat ensemble competitions became familiar events.

\footnotetext{
${ }^{13}$ The department was originally known in Thai as Krom Mahorasop Luang. In the reign of King Rama VII, it was called Krom Piphat and Khon Luang.
} 
Although the traditional competitions occurred quite often, in the new social context in the reign of King Rama V only the rich could afford to patronize an artist. A sign of the patron's high status, a fostered artist who could defeat all rivals brought the supporter great pride and reputation. Piphat artists were supported in terms of social status and skill sharpening. For example, Nai Sorn, the talented ranadek xylophonist, once under the patronage of Prince Phanu Phantuwong Waradej, was showered with a package of lessons from outstanding masters, an ordination ceremony, and wedding festivities. Later, he was appointed Chang Wang Sorn, working as head of the royal pages. Similarly, Nai Thua, the piphat master, conducting the ensemble under the patronage of Prince Nakornsawan Warapinit, was appointed Chang Wang Thua and regularly showered with gifts and money.

Given such patronage, the artists were allowed to dedicate their lives to creating beautiful music and had many opportunities to start their rise to fame while performing in major events. Undoubtedly, famous artists-cumcustom setters were found in the reign of King Rama V among those under the patronage of such high dignitaries as Phraya Prasan Duriyasup (Plaek Prasansup), ensemble conductor of the crown prince, Chang Wang Thua Pathayakosol, ensemble conductor of the Bang Khun Phrom palace, Luang Pradith Pairoh (Sorn Silapabanleng), ensemble musician of the Burapha palace, etc. Without direct effect on the structural development of piphat, patronage helped improve artistic skills and give birth to each school's thang, ${ }^{14}$ or playing manner and techniques.

Although the manners of melodic execution differed from school to school, these masterpieces were considered classic, and their influence has been handed down from generation to generation. To be widely acclaimed, musicians, generally, had to learn playing techniques from fostered artists. As students of Phraya Sanoh Duriyang (Cham Sunthornwathin), members of the Duriyapraneet family even dating back to the early Ratanakosin period learnt and inherited his playing techniques.

Derived from the talents of piphat artists under high dignitaries' patronage, different playing techniques initiated in this period gradually laid the foundation for the national music ensemble with continued court support in the following reigns. Particularly fond of entertainment culture, which was considered an expression of the country's civilization, King Rama VI gave first priority to the support of the royal ballet troupes and musical arts. According to Cha-muen Amorn Darunaruk (Cham Sunthornvej), 'His Majesty intended to conserve and promote these dance theaters and musical performances for the prestige of the country' (vol. IV, 1968: 140).

\footnotetext{
${ }^{14}$ Thang in music means the specially designed procession of notes in songs. Though played on the same instrument to the same song, different thang gave different melodies. Thang was used not only in piphat but in other kinds of ensemble, as well. Nowadays, there are four thang in playing Thai classical music, designed by the great teachers of piphat under the patronage of the court and the elites in the reign of King Rama V: the thang of Phraya Prasan Durisub (Plaek Prasansub), the thang of Phraya Sanoh Duriyang (Chaem Sunthornwathin), the thang of Chang Wang Thua Pathayakoson, and the thang of Luang Pradit Pairoh (Sorn Silapabanleng).
} 
A royal decree was therefore promulgated to regulate their standard practice and to bring competent artists together in the palace. A large number of talented musicians were recruited into royal service with incentive titles, making the court the performing arts center with the greatest influence on the handing down of artistic tradition. ${ }^{15}$

Without constant promotion by the royal court as a symbol and source of national prestige, the classical performing and musical arts would not have been passed on to the present day. To establish and develop their foundation in the reign of King Rama $\mathrm{V}$, the high dignitaries' efforts were historically crucial in transmitting the arts before European performing arts infiltrating Thai culture in the forms of modern Thai songs, movies, and ballroom dance became widely embraced by society.

\section{Conclusion}

Originating as an important part of the solemn tradition of religious beliefs, Thai entertainment culture has developed in response to the public's changing desires. The critical factors influencing these modifications were based in historical conditions, especially the economic growth of the early Ratanakosin period. The court's role and the behavior of commoners

\footnotetext{
${ }^{15}$ In 1935 , the government transferred the administration of music and classical performing arts from Krom Mahorasop Luang to the Fine Arts Department. Artists under the patronage of the court were also transferred to the new department. This transfer helped the court entertainment culture flourish down to present.
}

changed so much that the ceremonial solemnity of the earlier culture was replaced by increasingly popularized forms. Once the public gained more income, the rich liked to show off their social status by hosting ceremonies accompanied by musical and performing arts, which resulted in prosperity for the artists and led to these artists' devotion to creating a wider variety of entertainment.

The critical change in Thai entertainment culture occurred during the reign of King Rama V. Economic growth and the reform of the country turned collective amusements into individual and paid entertainment. Simultaneously, under the influence of European civilization, modern Thai entertainment produced a perfect blend of styles in the national arena. This change marked the beginning of Occidental infiltration into Thai entertainment. Although efforts were made by the authorities and high dignitaries to blend Western culture and create some innovations, the royal court's traditions and culture were handed down and systemized so that the standard practice of the classical arts could be established, protected, and preserved as part of the Thai national heritage under the supervision of the Fine Arts Department.

\section{References}

\section{Bradley, Dan Beech. 1971. Dictionary of the} Siamese Language 1873. Bangkok: Kurusapa.

Choisy, Abbé de. 1977. Journal du voyage de Siam. Translated by San T. Komolbutr. Bangkok: Kaona. [In Thai].

Damrong Rajanubhab, H.R.H. Prince. 1965. Tamnan Lakhon Inao. Bangkok: Khlang Witthaya. [In Thai]. 
Darunaruk, Amorn. 1971. The Achievements of King Rama $V I$. Bangkok: Kurusapa. [In Thai].

Harris, Thousend. 1961. Daily Report of Thousend Harris. Translated by Nanta Woranatiwong. Bangkok: Satsana. [In Thai].

Kham Hai Karn Khun Luang Wat Pradoo Songtham. 1991. Bangkok: Secretary of the Ministry Cabinet. [In Thai].

La Loubère, Simon de. 1967. A New Historical Relation of the Kingdom of Siam. Translated by San T. Komolbutr. Bangkok: Kurusapa. [In Thai].

Latthi Thamniam Tang Tang. 1972. $5^{\text {th }}$ ed. Bangkok: Chareonrat Press.

Naikuadhumprae. 1918. Mahorasop in Present Reign. Dusit Samit 1: 39. [In Thai].

Narintharadavee, Krommlaung. 1978. The Chronicles of Krom Luang Narinthara Dhevi's Memoirs and the Commentary of King Rama V. Funeral Ceremony of Prachaoborommawongther Phraongchaowapeebusakorn. Bangkok: Ammarinkarnpim. [In Thai].

Pallegoix. 1977. Laoreuang Krung Siam. Translated by San T. Komolbutr. Bangkok: Sumnakpimkaona. [In Thai].

Phachum Pongsawadan, Part II. 1963. Pranakorn: Kurusapa. [In Thai].

Prachum Silacharuk part I, Charuk Sukhothai. 1977. Ed. by Nakhon Pantunarong. Phisanulok: Srinakarintaraviroj University Press. [In Thai].
Prachumprakat Ratchakarn of King Rama IV. 1961. Bangkok: Kurusapa. [In Thai].

Rama IV, King. 1978. The Letter of King Rama IV. Bangkok: Mahamongkut Press. [In Thai].

Rama V, King. 1970. Klai Ban. Pranakorn: Praepitthaya. [In Thai].

Rama V, King. 1905. The Speech of King Rama V [1875-1910]. Bangkok: Soponpipattanakorn. [In Thai].

Royal Institute Dictionary 1982. 1982. Bangkok: Aksorn Charoentad. [In Thai].

Royal Institute Dictionary 1999. 2003. Bangkok: Siriwattanainterprint. [In Thai].

Saraya, Dhida. 1996. Thai Civilization. Bangkok: Muangboran. [In Thai].

Sepa Khun Chang Khun Pan. 1970. Thonburi: Rungwattana. [In Thai].

Siam Sa Mai Report. 1884. Sansernlakhorn Prince Theatre. Vol. 2. [In Thai].

Silapakorn, Krom. 1976. Kan Sadaeng Natasin lae Dontri Thai. Bangkok: Kurusapa. [In Thai].

Silapakorn, Krom. 1986. Silapa Wattanatham Thai: Nataduriyangkhasinthai Krung Rattanakosin. Vol. 7. [In Thai].

Thai Classical Music. 1986. Bangkok: Sasana. [In Thai].

Tra Sam Duang Law. 1972. Vol. 1. 2nd ed. Bangkok: Kurusapa. [In Thai].

The Confession of the Residents of the Old Capital and the Confession of Khun Luang Ha Wat. 1982. Bangkok: Khlang Witthaya. [In Thai].

Tiphakornwong, Chao Phraya. 1961. Prarajchapongsawadan Krung Rattanakosin. Vol. 2. Bangkok: Kurusapa. [In Thai].

U-Pho, Thanit. 1991. Khon. Bangkok: Institute of Thai Studies, Thammasart University. [In Thai]. 